\title{
Proton Exchange Membrane Electrolyzer Systems Operating Dynamically at High Current Densities
}

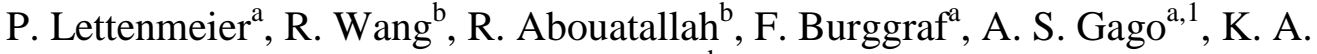 \\ Friedrich $^{\mathrm{a}, \mathrm{b}}$ \\ ${ }^{a}$ Institute of Engineering Thermodynamics, German Aerospace Center, \\ Pfaffenwaldring 38-40, Stuttgart, 70569, Germany \\ ${ }^{\mathrm{b}}$ Hydrogenics Corporation, 220 Admiral Boulevard, Mississauga, ON L5T 2N6, \\ Canada \\ ${ }^{c}$ Institute of Energy Storage, University of Stuttgart, Stuttgart, 70550, Germany
}

The fluctuating behavior of renewable energy sources hinders the widespread integration of those in a reliable electricity grid. Presumably, the wide operation range and rapid response of proton exchange membrane (PEM) electrolyzers can stabilize the grid, yet the degradation effects are not fully understood. The results presented here show no negative effect of dynamic operation at current $0.8,1.6,2.5$ and $3.3 \mathrm{~A} \mathrm{~cm}^{-2}$, on commercial membrane electrode assemblies (MEA) with two different catalyst loadings. Conversely, the reduction of the loading of precious metal in the MEA leads to a cell voltage increase by $100 \mathrm{mV}$ at $3.3 \mathrm{~A} \mathrm{~cm}^{-2}$. In addition, stack temperature correction of industrial facilities is necessary for proper comparison of cell potential and analysis of degradation mechanisms.

\section{Introduction}

Renewable energies produced by wind or solar continuously gain importance and share in the power supply system. They help to reduce the global greenhouse gas emission and are the main technologies for reaching the $2{ }^{\circ} \mathrm{C}$ average temperature limit agreed by all parties of the United Nations Conference on Climate Change 2015 (COP 21) (1). Besides all the positive aspects, renewables provide fluctuating power thereby contributing to challenges to balance the electricity grid (2). Especially in Germany, the renewables already contribute to a significant percentage of over the $30 \%$ of the electrical energy production (3). Consequently, the integration of those fluctuating energy sources have become a hot topic (4). Scenarios for a more flexible electricity system includes upgrading the transmission network, large energy storage systems, demand-sidemanagement (DSM) and the increasing the power reserve. As a technology, polymer exchange membrane (PEM) electrolyzer is able to provide three of the mentioned scenarios. PEM electrolyzer splits water in oxygen and hydrogen from electricity and the hydrogen can be stored either in pressurized tanks, large salt caverns or other options (5). The produced hydrogen has a high purity of $99.995 \%$ (6) and can be pressurized during electrolysis $(7,8)$. PEM electrolysis is highly dynamic and can fulfill the requirements for control power $(9,10)$. Depending on the national rules, a minimum power is needed for

${ }^{1}$ Corresponding author: Tel.: +49 711 6862-8090, fax: +49 711 6862-747, e-mail address: aldo.gago@dlr.de (A. S. Gago). 
control application, but this is not a significant barrier for electrolysis installations due to the modular nature of the technology.

There is still not much information available on the dynamic operation of PEM electrolysis at partial- and over-loads. A typical test is to provide the qualification profile for control power or to run a representative wind power profile. However, these tests will not provide much information on the degradation behavior. In this work, we provide a systematic approach for characterizing constant and highly dynamic operation modes and their impact on efficiency. We also investigate the influence of catalyst loadings in order to detect possible cost savings of precious metals as its scarcity may pose economic difficulties for PEM electrolyzer market in the gigawatt range (11). It has been reported that structural optimization of catalysts (12-15) as well as reducing the catalyst loading (16) is one of the key questions for this challenge.

\section{Experimental}

\section{$\underline{\text { PEM electrolyzer system }}$}

The test bench used in this study, HyLYZER ${ }^{\mathrm{TM}}$ Hydrogen Generator (HHG) from Hydrogenics, is a commercial PEM electrolyzer designed for $2.5 \mathrm{Nm}^{3} \mathrm{~h}^{-1}$ hydrogen production rate with a 40-cell stack (model E92). However, in this work the stack is only comprised of eight cells of $120 \mathrm{~cm}^{2}$ with MEAs from the company Greenerity (former SolviCore). These MEAs have an active area of $120 \mathrm{~cm}^{2}$, and are made from Nafion ${ }^{\mathrm{TM}}$ N115CS membrane. According to the provider, four cells have a reduced (R) precious group metal (PMG) loading of $2.4 \mathrm{mg} \mathrm{cm}^{-2}$ and the rest have a standard (S) loading of 3$3.5 \mathrm{mg} \mathrm{cm}{ }^{-2}$. Table 1 summarizes the arrangement of these MEAs in the stack. Electrochemical impedance spectroscopy (EIS) was performed using a Zahner elektrik IM6 and booster (Module PP240) potentiostat/galvanostat. EIS measurements were performed at $30 \mathrm{~A}\left(0.25 \mathrm{~A} \mathrm{~cm}^{-2}\right)$, at frequencies between 0.1 and $750 \mathrm{~Hz}$, with an amplitude of $3.8 \mathrm{~A}$ and at $30^{\circ} \mathrm{C}$.

TABLE I. Arrangement of MEAs in Stack.

\begin{tabular}{ccccc}
\hline Cell number & Provider & Model & PEM & $\begin{array}{l}\text { PMG loading } \\
{\left[\mathbf{m g ~ c m}^{-2}\right]}\end{array}$ \\
\hline $1(\mathrm{SA})^{\mathrm{a} 2}$ & Greenerity & SC-E300 & N115CS & $<2.4(\mathrm{R})$ \\
2 & Greenerity & SC-E300 & N115CS & $<2.4(\mathrm{R})$ \\
3 & Greenerity & SC-E300 & N115CS & $<2.4(\mathrm{R})$ \\
4 & Greenerity & SC-E300 & N115CS & $<2.4(\mathrm{R})$ \\
5 & Greenerity & SC-E300 & N115CS & $3-3.5(\mathrm{~S})$ \\
6 & Greenerity & SC-E300 & N115CS & $3-3.5(\mathrm{~S})$ \\
7 & Greenerity & SC-E300 & N115CS & $3-3.5(\mathrm{~S})$ \\
$8(\mathrm{SC})^{\mathrm{b3}}$ & Greenerity & SC-E300 & N115CS & $3-3.5(\mathrm{~S})$ \\
\hline
\end{tabular}

${ }^{a}$ In contact to the anode endplate connected to the (+) terminal of the rectifier. Water inlet / Water $+\mathrm{O}_{2}$ outlet

${ }^{b}$ In contact to the cathode endplate connected to the (-) terminal of the rectifier: $\mathrm{H}_{2}$ outlet

\section{$\underline{\text { Protocol of measurements }}$}

\footnotetext{
${ }^{2}$ In contact to the anode endplate connected to the $(+)$ terminal of the rectifier. Water inlet $/ \mathrm{Water}+\mathrm{O}_{2}$ outlet

${ }^{3}$ In contact to the cathode endplate connected to the (-) terminal of the rectifier: $\mathrm{H} 2$ outlet
} 
An accelerated stress test (AST) protocol was conceived in order to gain as much information as possible on system aspects of the HHG unit and on the mechanism of stack degradation. A scheme of this protocol is presented in Figure 1. The protocol consists of operation in a stationary and subsequently a dynamic mode. In the dynamic mode, the current density is changed from $0.08 \mathrm{~A} \mathrm{~cm}^{-2}$ to an upper limit in about $0.01 \mathrm{~s}$. The frequency of the applied current square wave was $0.5 \mathrm{~Hz}$. The upper limit of current density of the electrolyzer was gradually increased by $0.8 \mathrm{~A} \mathrm{~cm}^{-2}$ every two weeks. Each week the electrolyzer was operating in different modes: firstly in constant or stationary mode and subsequently under dynamic regime. Thus, it was possible to explore the HHG system and stack behavior at moderate current densities $\left(1-2 \mathrm{~A} \mathrm{~cm}^{-2}\right)$ and at higher current densities $\left(2-5 \mathrm{~A} \mathrm{~cm}^{-2}\right)$. A cell voltage - current density $\left(\mathrm{E}_{\text {cell- }} \mathrm{j}\right)$ characteristic was recorded at the end of each week in order to reveal possible irreversible changes of the stack components.

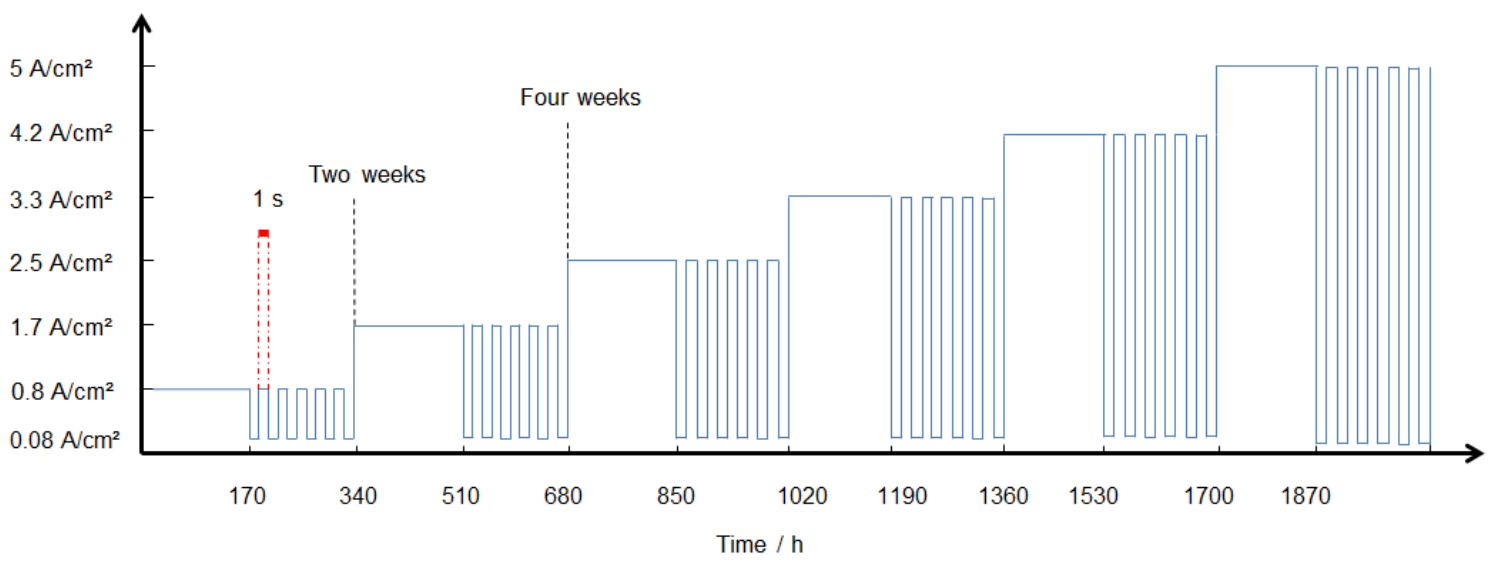

Figure 1. Scheme of the current-time input AST protocol showing the intercalating constant / dynamic operation modes.

A general overview of the output rectifier current and stack voltage vs. time, as well as the input power, following the planed AST protocol of Figure 1 is presented in Figure $2 \mathrm{a}, 2 \mathrm{~b}$ and $2 \mathrm{c}$, respectively. The time-periods in which the line is broken correspond to system shut downs due to laboratory incidents. 

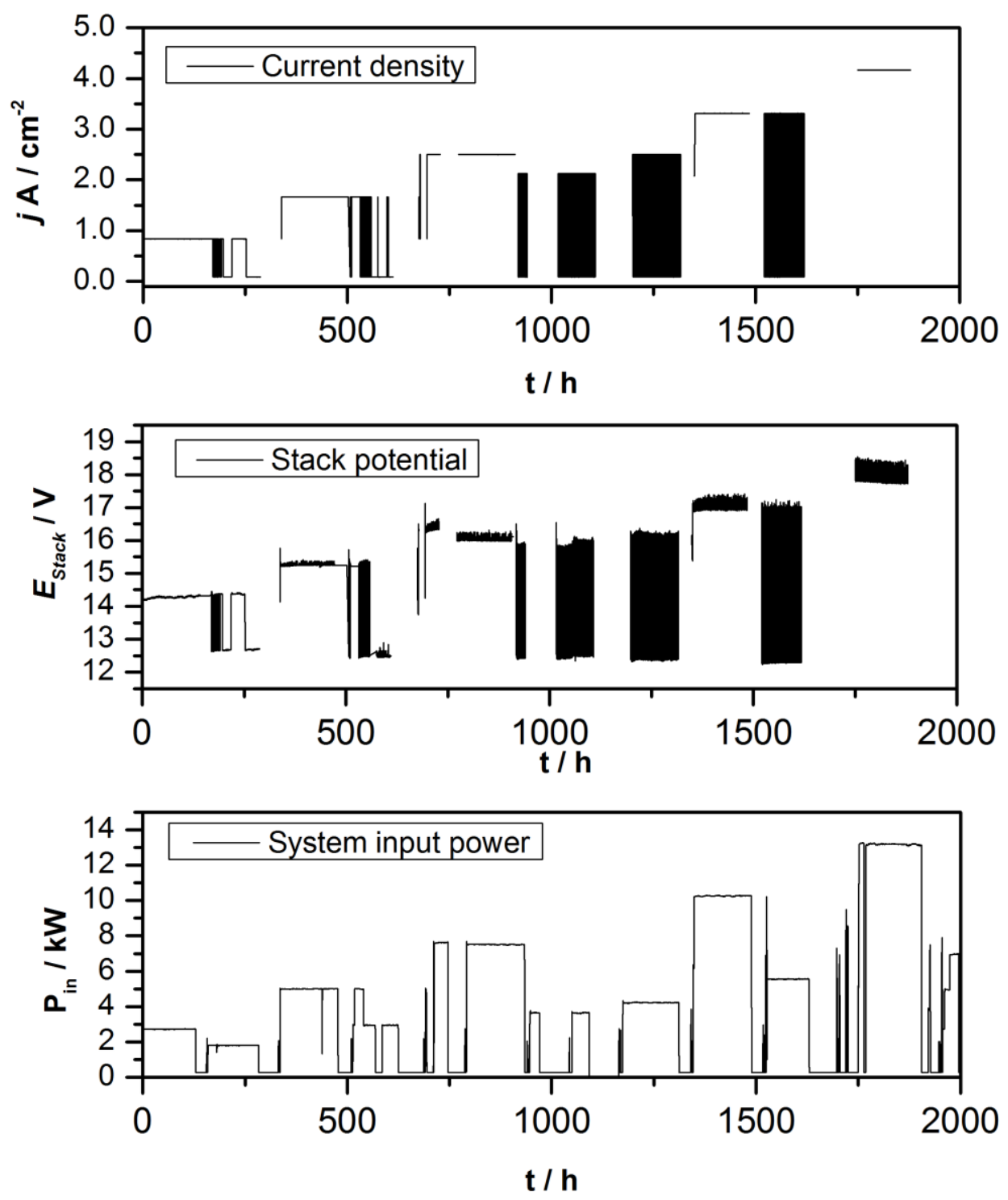

Figure 2. Output (a) rectifier current, (b) stack voltage and c) input power with respect to operation hours in stationary and dynamic modes.

\section{Results and discussion}

\section{Influence of PMG loading in the CCMs}

According to Greenerity specifications, the first four cells of this stack have a reduced PGM loading of $2.4 \mathrm{mg} \mathrm{cm}^{-2}$. The rest of the cells have $30 \%$ higher loading than the first four. The reduction of the PMG loading in the MEAs leads to an increase of the cell potential $\left(\mathrm{E}_{\text {cell }}\right)$ of about $50 \mathrm{mV}$ measured at $1.25 \mathrm{~A} \mathrm{~cm}^{-2}$ under constant loading mode, Figure 3a. Thus an 8-cell stack with $3.5 \mathrm{mg} \mathrm{cm}^{-2}$ in each MEA increases $3.5 \%$ the stack efficiency and approx. $2 \%$ the efficiency of the total system compared with a system having an 8-cell stack with $2.4 \mathrm{mg} \mathrm{cm}^{-2}$. 

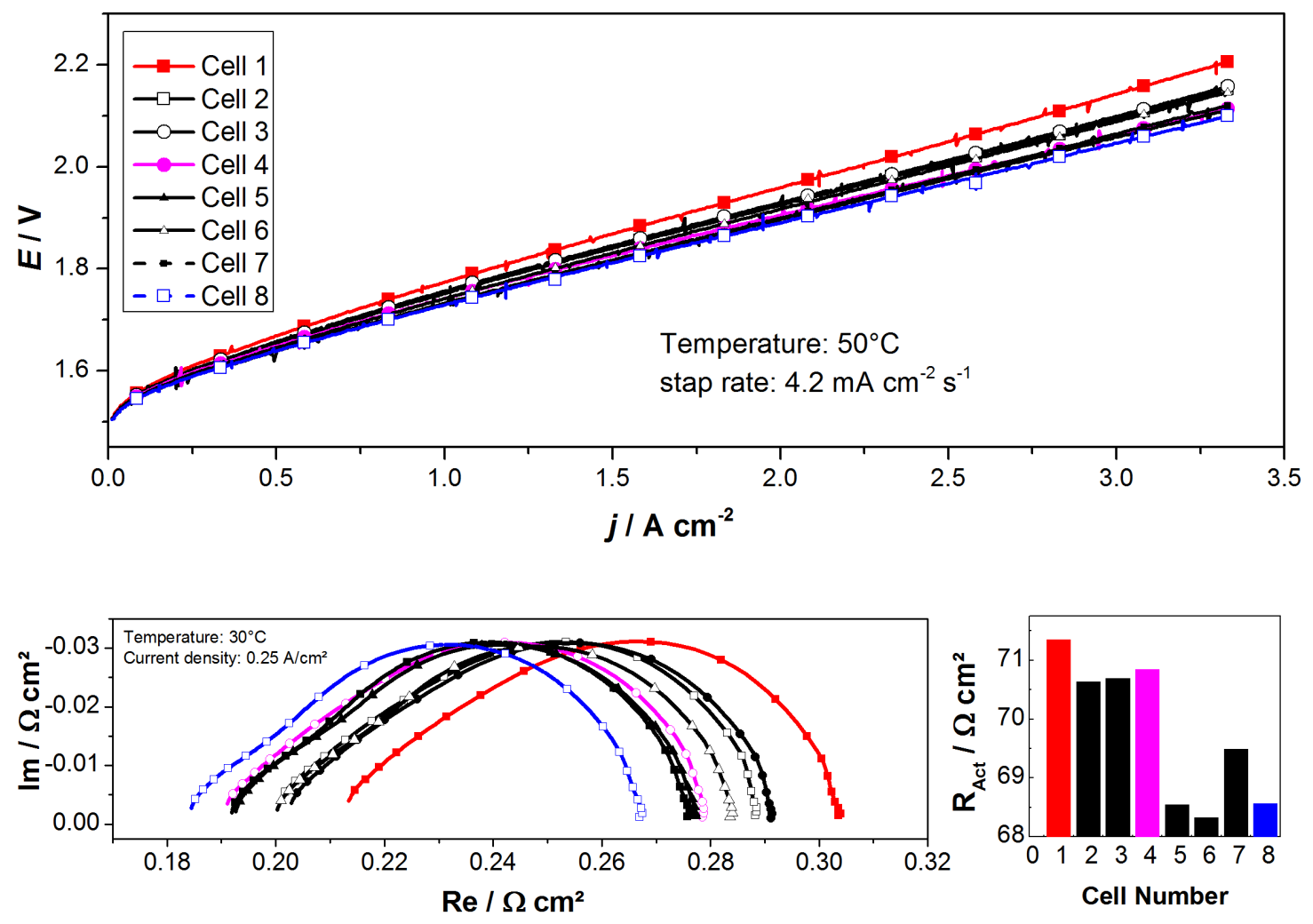

Figure 3. a) Cell voltage vs. stack current characteristics of Stack 1. Cell 1-4 and 5-8 have reduced and standard PMG, respectively. Measurements were performed at $50{ }^{\circ} \mathrm{C}$ and 8 bar. The rectifier step rate was $4.2 \mathrm{~mA} \mathrm{~cm}^{-2} \mathrm{~s}^{-1}$. b) Nyquist diagram of all cells at $25 \mathrm{~A}$ $\mathrm{cm}^{-2}$ and at $30^{\circ} \mathrm{C}$. c) Kinetic resistance related to the activation overpotential at $25 \mathrm{~A} \mathrm{~cm}^{-}$ ${ }^{2}$ and at $30^{\circ} \mathrm{C}$.

Cell 1 shows the lowest performance corresponding to the highest ohmic resistance, which is related to the $\mathrm{x}$-axis interception at high frequencies in the Nyquist plot. Figure $3 \mathrm{c}$ shows, that cell 1 has additionally the highest impedance corresponding to the charge transfer resistance analyzed by a $\mathrm{R}_{1}-\mathrm{CPE} / \mathrm{R}_{2}-\mathrm{CPE} / \mathrm{R}_{\text {Act }}$ equivalent circuit, which indicates the lowest kinetic property. Cell 1 to 4 have in general a higher charge transfer resistance than cell 5 to 8, which can be explained by the lower catalyst loading. Cell 8 is the cell with the highest efficiency. Interestingly, it does not have the lowest charge transfer resistance, but it has the lowest ohmic resistance. Lastly, cell 4 has the second best performance, even though it has a high charge transfer resistance but certainly the second lowest ohmic resistance. In general it can be concluded, that both parameters have a deep influence on the cell performance.

\section{$\underline{\text { Temperature dependence }}$}

Since water electrolysis is an exothermic reaction, a typical commercial PEM electrolysis system does not include any components that can provide external heat to the system. On the contrary, a system normally requires the removal of heat from the stack by means of reactant water and then through a heat exchanger. The heat exchanger normally starts when a maximum stack temperature set-point is reached. The HHG 
system used in the study was designed to a maximum input power of $30 \mathrm{~kW}$ to the stack. The 8-cell stack consumes approximately $12 \mathrm{~kW}$ power when the stack operates at $5 \mathrm{~A}$ $\mathrm{cm}^{-2}$. Thus the stack ran under at lower current density and thus under nominal operating temperature. Although the performance of the stack is highly dependent on temperature, the HHG system can only maintain a relatively constant temperature at high current densities close to design capacity at higher current density.

As an example, Figure $4 \mathrm{a}$ shows the $\mathrm{E}_{\text {cell }} \mathrm{j}$ characteristics of Cell 1 and Cell 8 measured by increasing $\mathrm{j}$ at a step rate of $4.2 \mathrm{~mA} \mathrm{~cm}^{-2} \mathrm{~s}^{-1}$ up to the maximum achievable current density. Firstly, it can be observed that between 0 and $2.5 \mathrm{~A} \mathrm{~cm}^{-2}$ the temperature is maintained at about $45{ }^{\circ} \mathrm{C}$, while it rises sharply afterwards up to $60{ }^{\circ} \mathrm{C}$ at $4.8 \mathrm{~A} \mathrm{~cm}^{-2}$. This rapid increment in the $T_{\text {stack }}$ causes a decrease in the $E_{\text {cell }}$ deforming the usual $E_{\text {cell }}-j$ linear shape. This issue makes difficult to analyze any mass transport or diffusion problem in the stack. At a current density of $4.8 \mathrm{~A} \mathrm{~cm}^{-2}$ the system operation was stopped because $\mathrm{E}_{\text {cell }}$ reached $2.5 \mathrm{~V}$ which is the voltage limit. The event happened because just before the temperature reached its limit and the fan start to cool down the system resulting in rapid voltage increase.

Consequently, the only way to obtain an $E_{\text {cell- }}-\mathrm{j}$ characteristic at a fixed temperature is by preheating the stack and recording the curve from higher to lower current densities such at it is shown in Figure $4 \mathrm{~b}$. The $\mathrm{E}_{\text {cell- }} \mathrm{j}$ curves of this figure were registered for $28.8 \pm$ $3.5{ }^{\circ} \mathrm{C}$ and $48.0 \pm 6{ }^{\circ} \mathrm{C}$. The difference between these two temperatures resulted in a reduction of the $E_{\text {cell }}$ of $75 \mathrm{mV}$ and $150 \mathrm{mV}$ at 1.25 and $3.3 \mathrm{~A} \mathrm{~cm}^{-2}$, respectively. Figure $4 \mathrm{~b}$ also depicts the obvious performance difference of normal and reduced catalyst loading for cell 8 and cell 1, respectively. There is a linear dependence of the $\mathrm{E}_{\text {cell }}$ and $\mathrm{T}_{\text {stack }}$ within a range of about $40{ }^{\circ} \mathrm{C}$, reported elsewhere (16). This correlation is useful for detecting variations $\mathrm{E}_{\text {cell }}$ due to degradation phenomena, when the $\mathrm{HHG}$ is operating in either constant or dynamic modes and eliminate minor temperature impacts. The same approach can be used for larger PEM electrolysis systems. 
a)

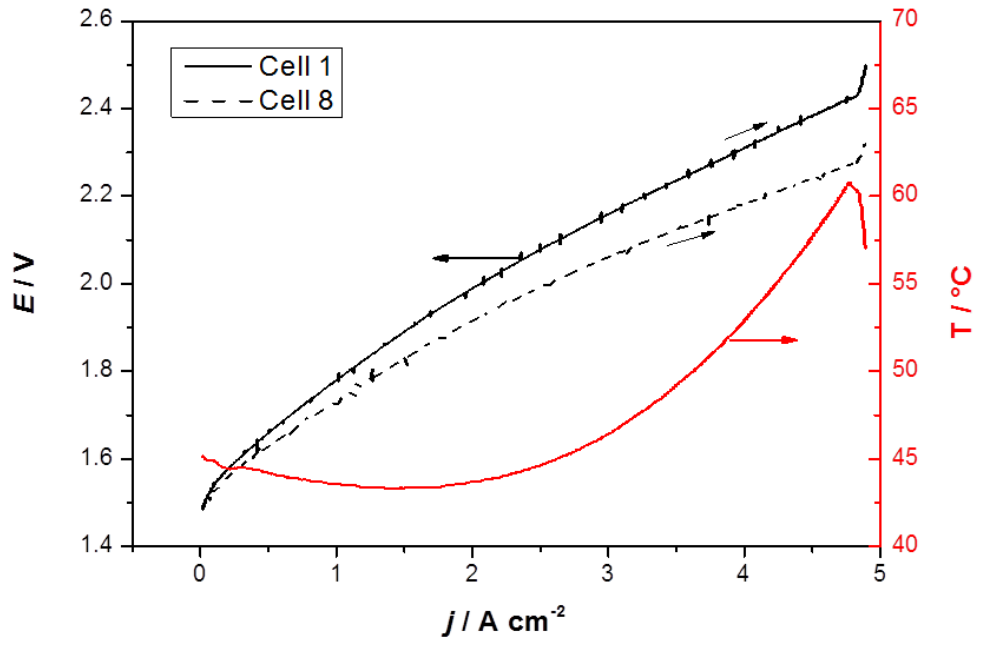

b)

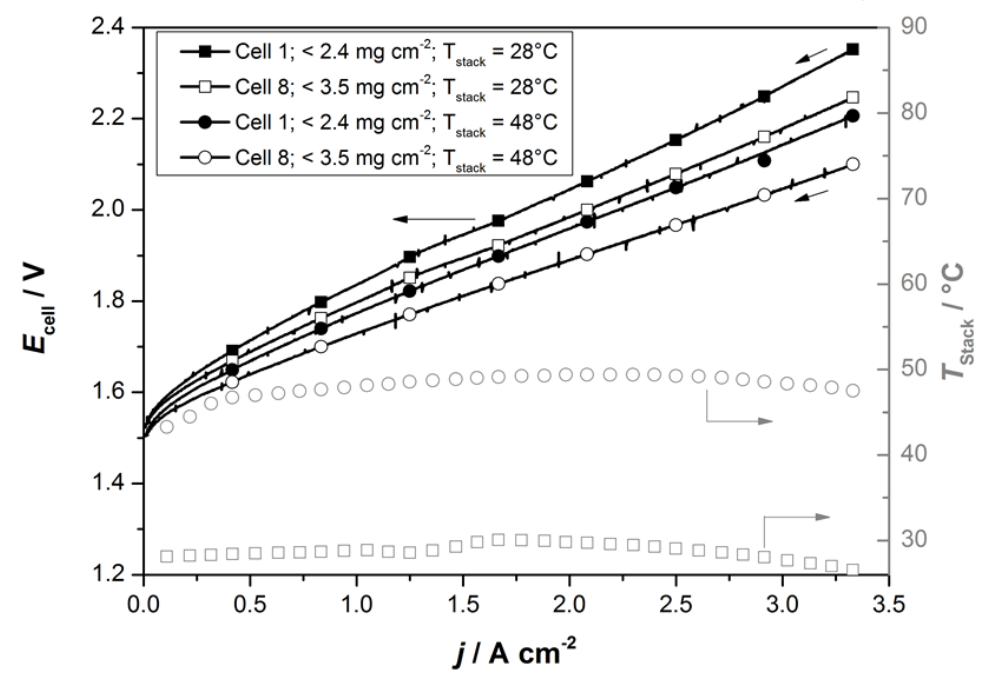

Figure 4. a) Cell voltage vs. current density characteristics of Cell 1 and 8 recorded when applying a load from 0 up to $5 \mathrm{~A} \mathrm{~cm}^{-2}$. b) Cell voltage - stack current characteristics of Cell 1 and 8 measured after $1600 \mathrm{~h}$ of operation measured at different temperatures. Measurements were performed at 8 bar. The rectifier step rate was $4.2 \mathrm{~mA} \mathrm{~cm}^{-2} \mathrm{~s}^{-1}$ and the arrows indicate the scanning the sense of the applied current density.

\section{Dynamic operation}

Dynamic operation was performed in order to study performance, response time and degradation under this condition. Figure 5 shows a $15 \mathrm{~s}$ interval period in which the HHG system was operating at a $j_{\max }$ of $1.7 \mathrm{~A} \mathrm{~cm}^{-2}$ and as $j_{\min }$ of $0.08 \mathrm{~A} \mathrm{~cm}^{-2}$. The input $\Delta \mathrm{j}$ last about $0.01 \mathrm{~s}$ while the output response $\Delta \mathrm{U}_{\text {stack }}$ is about $3 \mathrm{~V}$ lasting $0.01 \mathrm{~s}$ resulting in a $2 \%$ loss in the overall efficiency. These dynamic operation studies were performed up to current density of $4 \mathrm{~A} \mathrm{~cm}^{-2}$ which proves the fast response of this technology and the ability of PEM electrolysis to fulfill the requirements of primary control. During the milliseconds the PEM electrolyzer can provide positive and negative control power by operating at partial- or overload, respectively and can therefore be used for stabilizing electricity grids. 


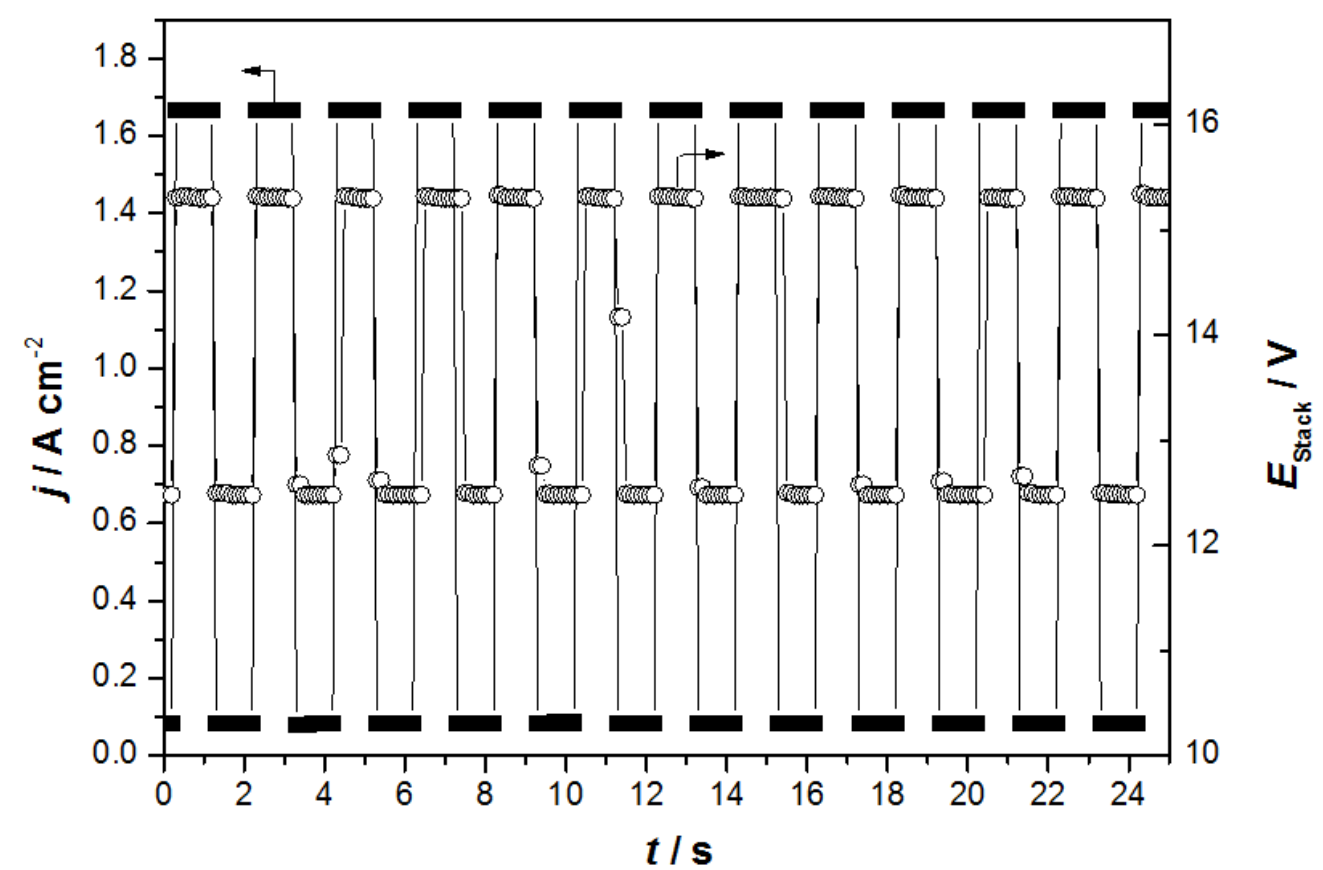

Fig. 5. Rectifier current density and stack voltage - time transient measured when the system was operating dynamically at a max. and min. current density of 1.7 and $0.08 \mathrm{~A} \mathrm{~cm}^{-2}$, respectively. The frequency of the applied current square wave is $0.5 \mathrm{~Hz}$.

\section{$\underline{\text { Degradation }}$}

Possible negative effects of constant and dynamic operation modes regarding degradation were investigated by performing and analyzing $E_{\text {cell }}-\mathrm{j}$ characteristic after each week of the performed protocol. Figure $6 \mathrm{a}$ and $\mathrm{b}$ show them separately after constant and dynamic operation mode, respectively. Remarkable is the different aging behavior at lower and higher current densities. While the recorded voltage decreases over time at current densities of $1.25 \mathrm{~A} \mathrm{~cm}^{-2}$ and higher, the voltage is increasing at lower current densities. It has been reported that two different degradation mechanism are responsible for this behavior (16). Decay of intrinsic catalyst activity results in a decrease of exchange current density and at low current densities the charge transfer overpotential is dominating the performance losses. At higher current densities, this effect is compensated by an opposite acting ohmic contribution. The ohmic resistance is decreasing during time, which results in increasing performance at higher current densities. However, the decrease of ohmic resistance is not yet fully explained. Improved electric behavior in the electrode layer (16), can be a plausible reason.

The trends of aging are the same for dynamic or static operation (see Figure 6a and 6b). Nevertheless, it seems that after constant operation, the trends are somewhat more pronounced. This observation can be supported by Figure 6c, which shows the analyzed potential at $1.25 \mathrm{~A} \mathrm{~cm}^{-2}$ after each operation mode. The zigzag behavior could come by possible regenerative effect after performing in dynamic operation mode. Between 500 and $1500 \mathrm{~h}$, the positive peaks are related to the characteristics after dynamic operation. However, the general trend is a progressive decrease in cell voltage even after performing at high current density. 
a)

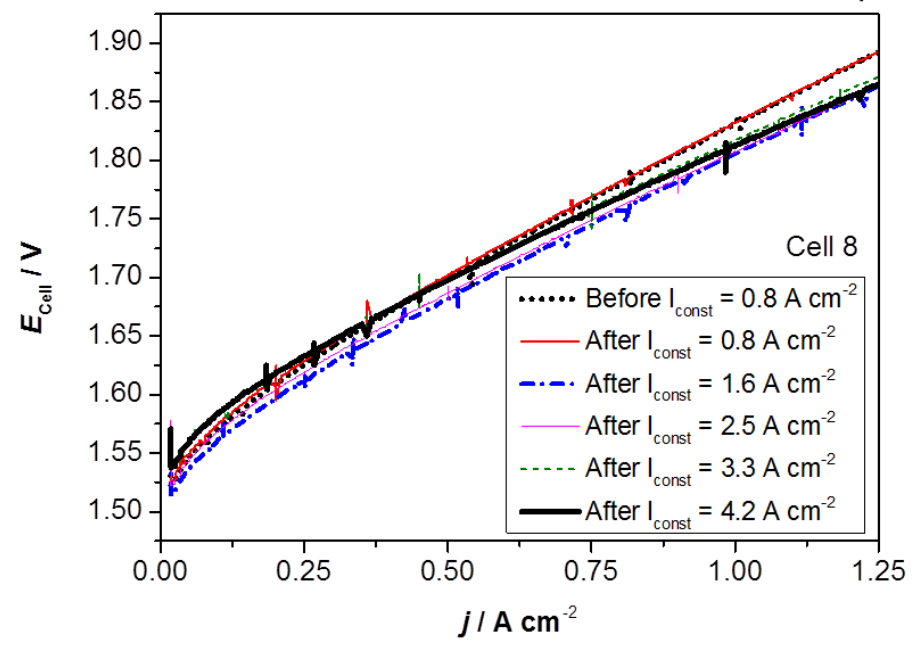

b)

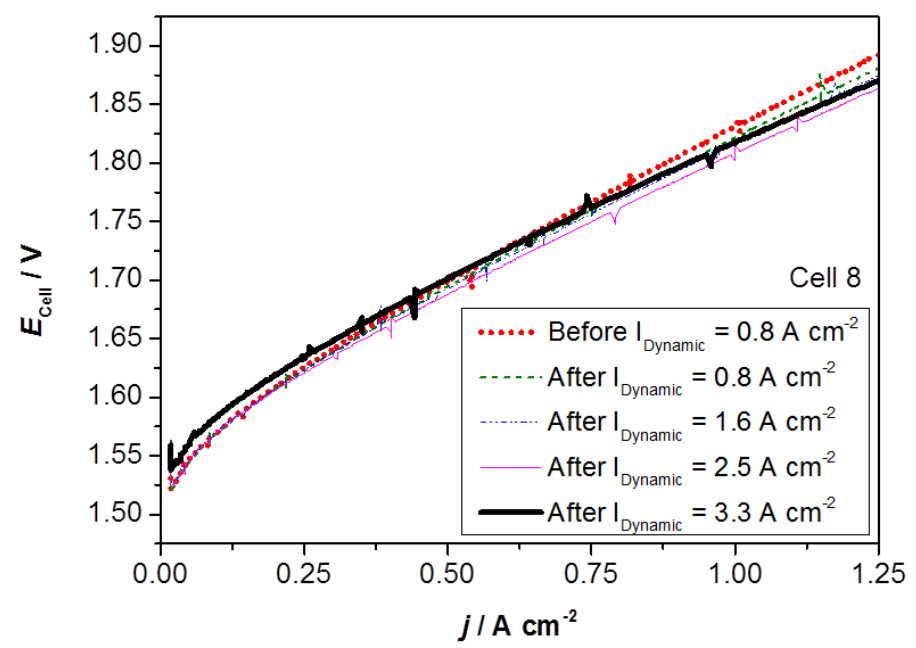

c)

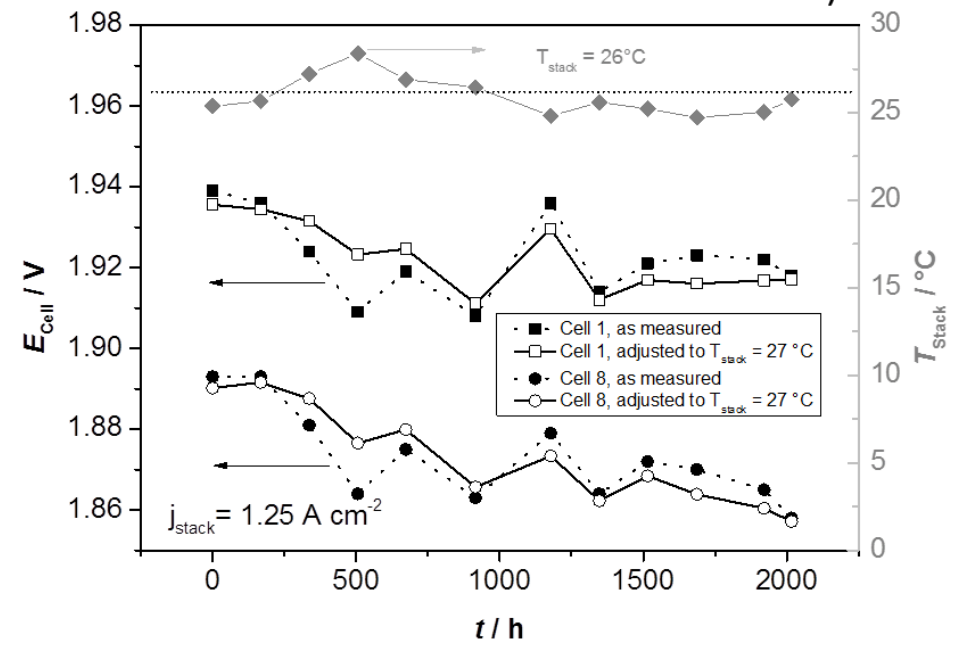

Fig. 6. Cell voltage vs. current density characteristics of Cell 8 recorded at around $26^{\circ} \mathrm{C}$ after each week of a) constant operation and b) dynamic operation. The rectifier step rate was $4.2 \mathrm{~mA} \mathrm{~cm}^{-2} \mathrm{~s}^{-1}$. c) Analysis of the potential of cell 8 at $1.25 \mathrm{~A} \mathrm{~cm}^{-2}$ after each week. 
The potential is shown as measured and after temperature correction of $5 \mathrm{mV} \mathrm{K}^{-1}$. Temperature of each measurement is shown on the right axis of diagram 6c.

\section{Conclusion}

We performed a systematic protocol to study the cell, the stack and the system behavior of an 8 cell stack with an active area of $120 \mathrm{~cm}^{2}$ under highly dynamic and constant conditions and at different current densities. Stack characterization by EIS and by $E_{\text {cell }}-\mathrm{j}$ characteristic shows a reduced charge transfer resistance and therefore an improved performance for MEAs with high catalyst loading. The hydrogen generator used for this study is not designed for operating at accurately controlled parameters which complicates the analysis of degradation. By temperature correction, degradation can be better analyzed and shows the general trend of decreasing cell potential. Dynamic operation mode seems not having a negative influence on degradation. Furthermore, a highly dynamic operation did not influence performance negatively. Furthermore the system reaction time is fast and allows fulfilling most control requirements in the grid.

\section{Acknowledgments}

The authors acknowledge the Federal Ministry for Economic Affairs and Energy (BMWi) for financial support in the project No. 0325440A.

\section{References}

1. Nations, U. ADOPTION OF THE PARIS AGREEMENT; 2015.

2. Nitsch, J.; Pregger, T.; Naegler, T.; Heide, D.; Tena, D. L. de; Trieb, F.; Scholz, Y.; Nienhaus, K.; Gerhardt, N.; Sterner, M.; Trost, T.; Oehsen, A. von; Schwinn, R.; Pape, C.; Hahn, H.; Wickert, M.; Wenzel, B. Langfristszenarien und Strategien für den Ausbau der erneuerbaren Energien in Deutschland bei Berücksichtigung der Entwicklung in Europa und global; 2012.

3. BMWi. Erneuerbare Energien auf einen Blick http://www.bmwi.de/DE/Themen/Energie/Erneuerbare-Energien/erneuerbare-energienauf-einen-blick.html.

4. Kohler, S. dena-Netzstudie II. - Integration erneuerbarer Energien in die deutsche Stromversorgung im Zeitraum 2015 - 2020 mit Ausblick 2025.; 2010.

5. Friedrich, K. A. Studie über die Planung einer Demonstrationsanlage zur Wasserstoff - Kraftstoffgewinnung durch Elektrolyse mit Zwischenspeicherung in Salzkavernen unter Druck; 2015.

6. Zeng, K.; Zhang, D. Prog. Energy Combust. Sci. 2010, 36 (3), 307-326.

7. Grigoriev, S. a.; Porembskiy, V. I.; Korobtsev, S. V.; Fateev, V. N.; Auprêtre, F.; Millet, P. Int. J. Hydrogen Energy 2011, 36 (3), 2721-2728.

8. Grigoriev, S. a.; Millet, P.; Korobtsev, S. V.; Porembskiy, V. I.; Pepic, M.; 
Etievant, C.; Puyenchet, C.; Fateev, V. N. Int. J. Hydrogen Energy 2009, 34 (14), 59865991.

9. Carmo, M.; Fritz, D. L.; Mergel, J.; Stolten, D. Int. J. Hydrogen Energy 2013, 38 (12), 4901-4934.

10. Eichman, J.; Harrison, K. W.; Peters, M. Novel Electrolyzer Applications: Providing More Than Just Hydrogen; National Renewable Energy Laboratory, 2014.

11. Vesborg, P. C. K.; Jaramillo, T. F. RSC Adv. 2012, 2 (21), 7933.

12. Lettenmeier, P.; Wang, L.; Golla-Schindler, U.; Gazdzicki, P.; Cañas, N. A.; Handl, M.; Hiesgen, R.; Hosseiny, S. S.; Gago, A. S.; Friedrich, K. A. Angew. Chemie 2016, 128 (2), 752-756.

13. Wang, L.; Lettenmeier, P.; Golla-Schindler, U.; Gazdzicki, P.; Cañas, N. A.; Morawietz, T.; Hiesgen, R.; Hosseiny, S. S.; Gago, A. S.; Friedrich, K. A. Phys. Chem. Chem. Phys. 2015, 18, 4487.

14. Lee, W. H.; Kim, H. Catal. Commun. 2011, 12 (6), 408-411.

15. Reier, T.; Pawolek, Z.; Cherevko, S.; Bruns, M.; Jones, T.; Teschner, D.; Selve, S.; Bergmann, A.; Nong, H. N.; Schlögl, R.; Mayrhofer, K. J. J.; Strasser, P. J. Am. Chem. Soc. 2015, 137 (40), 13031-13040.

16. Lettenmeier, P.; Wang, R.; Abouatallah, R.; Helmly, S.; Morawietz, T.; Hiesgen, R.; Kolb, S.; Burggraf, F.; Kallo, J.; Gago, A. S.; Friedrich, K. A. Electrochim. Acta 2016, $210,502-511$. 